\title{
Leucocyte adhesion deficiency type 1 with secondary haemophagocytic lymphohistiocytosis
}

\author{
A Halder ${ }^{1}$, *Subhasish Paul ${ }^{1}$, S Guha ${ }^{1}$, D Mitra ${ }^{1}$ \\ Sri Lanka Journal of Child Health, 2017: 46(2): 180-183 \\ DOI: http://dx.doi.org/10.4038/sljch.v46i2.8279 \\ (Key words: Leucocyte adhesion deficiency, haemophagocytic lymphohistiocytosis)
}

\begin{abstract}
Introduction
Leucocyte adhesion deficiency type 1 (LAD 1) is a rare disorder that occurs in 1 in 10 million births ${ }^{1}$. Only about 300 cases of LAD 1 have been reported worldwide $^{2}$. In India, even though there is a high rate of consanguinity, only a few cases of this recessive disorder have been reported ${ }^{3}$. Pathogenically, LAD is characterized by loss of the leucocyte ability to adhere to the endothelium during the inflammatory cascade, thus preventing their migration to the infected tissues. In a normal person, leucocytes first adhere to and roll along the wall of blood vessels using selectins and glycoconjugate ligands. They then adhere firmly and transmigrate using integrins and endothelial ligands. Total or partial absence of these molecules leads to $\mathrm{LAD}^{4}$.
\end{abstract}

\section{Case report}

A 7 month old male infant with a weight of $5.8 \mathrm{~kg}$, fully immunized to date, with normal developmental milestones, was admitted in April 2015 with high grade fever for 7 days and respiratory distress for 1 day. He was the first child of a non-consanguineous marriage, born at term by spontaneous vaginal delivery with a birth weight of $3.1 \mathrm{~kg}$, following an uncomplicated pregnancy. The umbilical cord separated at around the $10^{\text {th }}$ postnatal day. There was a history of perianal abscess since the $20^{\text {th }}$ day of life which was inadequately treated leading to multiple perianal fistulae. According to the mother, he was not gaining weight and had a history of frequent fever and recurrent infections including skin and soft tissue. There was a history of hospital admission at 3

${ }^{1}$ Vivekananda Institute of Medical Sciences, India

*Correspondence: dr.subho2010@gmail.com

(Received on 31 January 2016: Accepted after revision on 17 March 2016)

The authors declare that there are no conflicts of interest

Personal funding was used in formulating the article.

Open Access Article published under the Creative Commons Attribution CC-BY (c) (i) months of age for bronchopneumonia which was treated with intravenous (IV) antibiotics. There was no history of contact with tuberculosis and no history of prior pregnancy loss. Mother's maternal uncle had died at the age of 6 months from an unknown cause.

Examination revealed a pale febrile infant with tachypnoea and laboured breathing. He had firm hepatosplenomegaly and serosanguineous fluid oozing from multiple perianal fistulae (Figure 1). The other systems were normal.

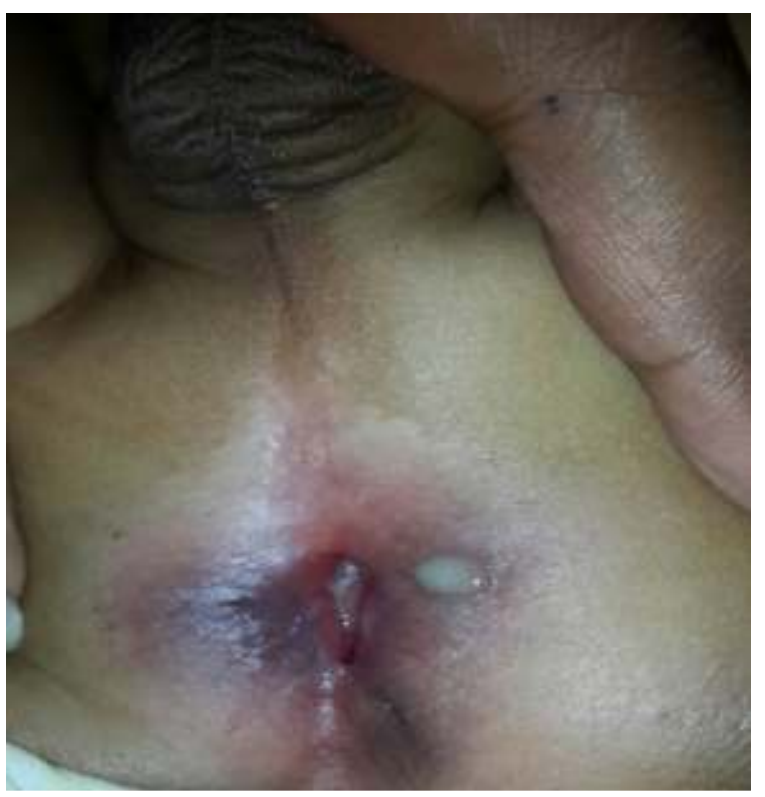

Figure 1: Perianal fistulae

The haemoglobin $(\mathrm{Hb})$ level was $8.4 \mathrm{~g} / \mathrm{dl}$. The total leucocyte count was 22,200/cu mm (N47, L44, M5, E4). C-reactive protein (CRP) was $24 \mathrm{mg} / \mathrm{L}$. Erythrocyte sedimentation rate (ESR) was $36 \mathrm{~mm}$ in the first hour. Serum ferritin was $179 \mathrm{mg} / \mathrm{dl}$. Serum electrolytes, renal and liver function tests were normal. Hepatitis viral profile and human immunodeficiency virus (HIV) were nonreactive. Mantoux test and gastric aspirate for acid fast bacilli were negative. Ultrasonography of abdomen showed hepatosplenomegaly without free fluid in abdomen. 
Chest $\mathrm{x}$-ray (CXR) showed right lung consolidation (Figure 2)

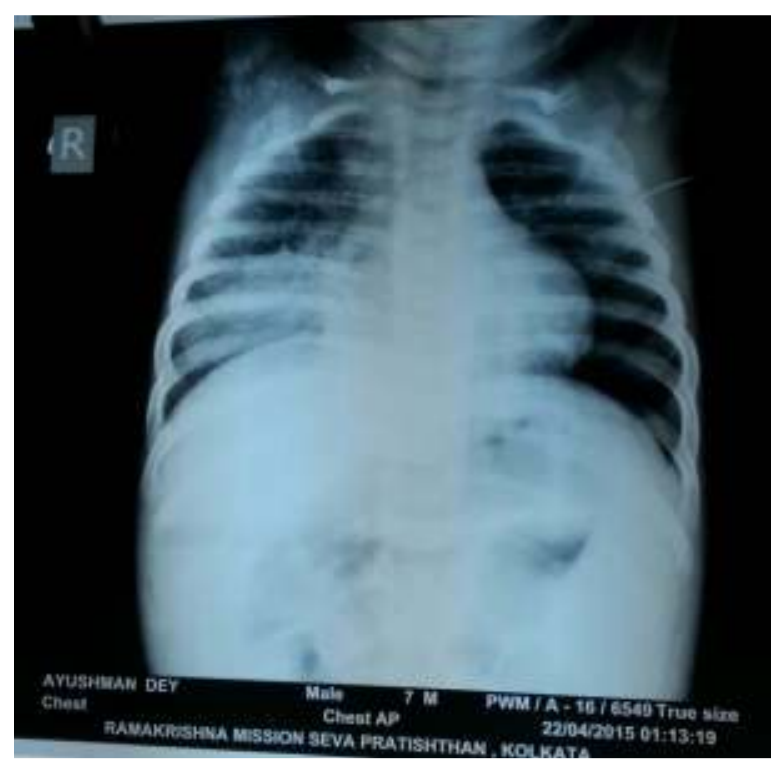

Figure 2: (R) lung consolidation on chest $x$-ray

Treatment was started with IV ceftriaxone. After 48 hours, infant continued to be febrile with worsening of tachypnoea. Antibiotics were upgraded to meropenem and vancomycin. Blood and urine cultures did not yield any growth and the cerebrospinal fluid study was normal. Fluid from perianal fistulae grew E. coli sensitive to meropenem.

In the background of frequent fever, recurrent infections and failure to thrive, a possibility of primary immunodeficiency (PID) was entertained. Immunoglobulin levels were normal. In addition, determinations of $\mathrm{CD} 4, \mathrm{CD} 8, \mathrm{CD} 4 / \mathrm{CD} 8$, by flow cytometry were normal. In view of recurrent fever, pneumonia and ischiorectal abscess, the possibility of a phagocytic defect was suspected. Nitroblue tetrazolium (NBT) and dihydrorhodamine (DHR) tests were however negative. The next differential diagnosis was leucocyte adhesion deficiency (LAD). Flow cytometric analysis of CD11b and CD18 were requested and turned out to be very low.

After 7 days, though the CXR showed resolution, child continued to be febrile. He was transfused with packed red blood cells for low $\mathrm{Hb}(5 \mathrm{~g} / \mathrm{dl})$. The continuous fever, multiple perianal fistulae and persistent leucocytosis prompted us to ask for a surgical opinion and repeat USG of abdomen was suggested which showed small multiple hypoechoic lesions in the spleen. In view of this report, bone marrow aspiration with biopsy was performed.
The next day (i.e. 17 days after admission) the infant deteriorated with lethargy, hypoglycaemia, abdominal distension and 2 episodes of generalized tonic convulsions. The infant was shifted to the paediatric intensive care unit for further management. Arterial blood gases and the serum electrolytes were normal. The prothrombin time (PT) and the activated partial thromboplastin time (aPTT) were prolonged, there being no coagulation. The haemoglobin $(\mathrm{Hb})$ was $10.3 \mathrm{~g} / \mathrm{dl}$ (post packed red cell transfusion) and the platelet count $35,000 / \mathrm{cu} \mathrm{mm}$. The total white cell count was $2800 / \mathrm{cu} \mathrm{mm}$ with an absolute neutrophil count of 560. The ESR was $06 \mathrm{~mm}$ in the first hour. The total bilirubin was $4 \mathrm{mg} / \mathrm{dl}$ (direct $3 \mathrm{mg} / \mathrm{dl}$ ). The SGPT was 586 IU and the SGOT 4212 IU. The serum albumin was $2 \mathrm{mg} / \mathrm{dl}$ and the serum globulin $3.3 \mathrm{mg} / \mathrm{dl}$. The serum triglycerides was $53 \mathrm{mg} / \mathrm{dl}$. The serum ferritin was 2000 IU. Bone marrow aspiration showed evidence of haemophagocytes. Bone marrow culture grew Acinetobacter which was sensitive to meropenem. The child received fresh frozen plasma (FFP) and platelet transfusion. Intravenous immunoglobulin (IVIG) was given. The clinical condition of the child further deteriorated requiring mechanical ventilation. Unfortunately he succumbed. The final diagnosis was primary immunodeficiencyleukocyte adhesion defect (LAD) complicated by secondary HLH due to infection.

\section{Discussion}

Adhesion molecule deficiencies have been classified into two types: LAD-1 and LAD-2, depending on the molecule that is defective, i.e. integrins in LAD-1 and selectins in LAD-2. Both forms of LAD have an autosomal recessive transmission pattern ${ }^{5}$. The severity is based on the relative expression of CD18, with less than $1 \%$ of normal described as severe and $2.5-10 \%$ of normal as moderate. In the variable form $\mathrm{CD} 18$ levels are normal but non functional ${ }^{6}$.

Patients with LAD-1 typically present with recurrent bacterial and fungal infections of the skin and mucosa, delayed detachment of the umbilical cord, rapidly progressive periodontitis, osteomyelitis and hepatosplenomegaly ${ }^{7-9}$. Rarely, life threatening complications like meningitis and septicaemia may occur $^{5,7,8}$. The diagnosis is suggested by the described findings, associated with persistent neutrophil leucocytosis. Flow cytometry is diagnostic and will show a notable decrease or absence of $\mathrm{CD} 18^{5,7}$. Confirmatory diagnosis depends on genetic analysis of beta 2 integrene gene ${ }^{5}$. LAD-2 is less common than LAD-1, but children are usually mentally retarded and present with failure to thrive, delayed growth, dysmorphic features and a Bombay blood phenotype ${ }^{5}$. As leucocytes start expressing 
CD11 and CD18 as early as 18-20 weeks of gestation prenatal diagnosis by cordocentesis may be useful ${ }^{3}$.

Our patient had a history of failure to thrive, recurrent infections, very early onset ischiorectal abscess, and a non-healing, non-purulent perianal ulcer. Whilst a granulocyte defect was initially suspected, this was ruled out by normal NBT \& DHR tests. LAD was confirmed by low CD18 and CD11b in flow cytometry. Genetic analysis was not possible because of financial constraints. In our patient the LAD was complicated by secondary HLH due to infection and he succumbed.

HLH is often the first manifestation of another PID syndrome ${ }^{10}$. It is an aggressive and life-threatening disorder of excessive immune activation and is most common in infants and young children ${ }^{11}$. It is a disorder of the mononuclear phagocyte system, characterized by proliferation and activation of benign histiocytes, causing dysfunction of various organs ${ }^{12}$. HLH can occur as a familial or sporadic disorder and the sporadic variety is often associated with infections or malignancy ${ }^{13}$. Single cases or small case series of HLH syndrome have been reported in a variety of PIDs and the clinical presentation of some of these cases has recently been summarized ${ }^{14}$. The condition may mimic a number of systemic disorders and diagnosis may be established by the use of standardized clinical and laboratory criteria ${ }^{15}$. Immuno-chemotherapy followed by allogenic BMT offers hope for long term survival in these patients ${ }^{13}$. Since this form of therapy is currently available in India ${ }^{16}$, early diagnosis of HLH is important so that appropriate treatment can be initiated. HLH can be of 2 types genetic and acquired $^{10}$. Genetic HLH can be divided into 2 groups - familial HLH and those associated with PIDS. Familial HLH is of 5 types depending on genetic defect. In many of the genetic defects an infection may be a triggering event and let the cytokine storm rolling ${ }^{17}$. Untreated, approximately $95 \%$ of children will die of the disease ${ }^{8}$. Even with currently recommended therapy, HLH is a frequently fatal condition, although spontaneous partial regression has been rarely reported ${ }^{9}$. Genetic HLH usually manifests within the first year of life in 70$80 \%$ of cases. Only $10 \%$ of cases may present in the neonatal period ${ }^{18}$.

Acknowledgements: We acknowledge the help given by Dr. Amit Rawat, Postgraduate Institute, Chandigarh India.

\section{References}

1. Webber EC, Church J, Rand TH, Shah AJ. Leukocyte adhesion deficiency in a female patient without delayed umbilical cord separation. Journal of Paediatrics and Child Health 2007; 43:406-8.

http://dx.doi.org/10.1111/j.14401754.2007.0 1089.x

PMid: 17489834

2. Etzioni A. Leukocyte Adhesion Deficiency (LAD) Syndromes. Orphanet Encyclopedia 2005; pp1-4.

3. Madkalkar M, Desai M. Clinical profile of Leucocyte Adhesion Deficiency Type 1. Indian Pediatrics 2012(49); 43-5. http://dx.doi.org/10.1007/s13312-012-00059

4. Netea MG, van der Meer JW. Immunodeficiency and genetic defects of pattern-recognition receptors. New England Journal of Medicine 2011; 364(1):60-70. http://dx.doi.org/10.1056/NEJMra1001976 PMid: 21208109

5. Bunting $M$, Harris ES, McIntyre TM, Prescott SM, Zimmerman GA. Leukocyte adhesion deficiency syndromes: adhesion and tethering defects involving beta 2 integrins and selectins ligands. Current Opinion in Hematology 2002; 9(1):30-5. http://dx.doi.org/10.1097/000627522002010 00-00006

PMid: 11753075

6. Lakshman R, Finn A. Neutrophil disorders and their management. Journal of Clinical Pathology 2001; 54: 7-19.

http://dx.doi.org/10.1136/jcp.54.1.7

PMid: 11271792 PMCid: PMC1731272

7. Crowley CA, Curnutte JT, Rosin RE, et al. An inherited abnormality of neutrophil adhesion. Its genetic transmission and its association with a missing protein. New England Journal of Medicine 1980; 302(21):1163-8. http://dx.doi.org/10.1056/NEJM1980052230 22102

PMid: 7366657 
8. Mellouli F, Ksouri H, Barbouche R, et al. Successful treatment of Fusarium solaniecthyma gangrenosum in a patient affected by leukocyte adhesion deficiency type 1 with granulocytes transfusions. $B M C$ Dermatology 2010; 10:10. http://dx.doi.org/10.1186/1471-5945-10-10 PMid: 20929531 PMCid: PMC2959010

9. Jabbari Azad F, Ardalan M, HoseinpoorRafati A, Sotoudeh S, Pourpak Z. Osteomyelitis in leukocyte adhesion deficiency type 1 syndrome. Journal of Infection in Developing Countries 2010; 4(3): 175-8.

PMid: 20351460

10. Janka GE. Familial and acquired haemophagocytic lymphohistiocytosis.

Annual Review of Medicine 2012; 63:23346.

http://dx.doi.org/10.1146/annurev-med-

041610-134208

PMid: 22248322

11. Farquhar J, Claireaux A. Familial haemophagocytic reticulosis. Archives of Disease in Childhood 1952; 27: 519-25. http://dx.doi.org/10.1136/adc.27.136.519

PMid: 13008468 PMCid: PMC1988563

12. Loy T, Alberto AD, Perry MC. Familial erythrophagocytic lymphohistiocytosis. Seminars in Oncology 1991; 18:34-9.

PMid: 1992522

13. Henter JI, Arico M, Elinder G, Imashuku S, Janka G. Familial haemophagocytic lymphohistiocytosis. Hematology Oncology Clinics of North America 1998; 12: 417-33. http://dx.doi.org/10.1016/S08898588(05)70 520-7
14. Faitelson Y, Grunebaum E. Haemophagocyt ic lymphohistiocytosis and primary immune deficiency disorders. Clinical Immunology 2014; 155(1):118-25.

http://dx.doi.org/10.1016/j.clim.2014.09.008 PMid: 25241079

15. Henter JI, Elinder G, Ost A, and the FHL study group of the Histiocytic Society. Diagnostic guidelines for haemophagocytic lymphohistiocytosis. Seminars in Oncology 1991; 18: 29-33.

PMid: 1992521

16. Mathew LG, Chandy M, Dennison D, Srivastav A, Ganapathy K, Cherian T. Successful bone marrow transplantation in an infant with Wiskott-Aldrich syndrome. Indian Pediatrics 1999; 36: 707-10.

PMid: 10740310

17. Clementi R, Emmi L, Maccario R, et al. Adult onset and atypical presentation of haemophagocytic lymphohistiocytosis in siblings carrying PRF1 mutations. Blood 2002; 100:2266-7. http://dx.doi.org/10.1182/blood-2002-041030

PMid: 12229880

18. Verbsky JW, Grossman WJ. Haemophagocytic lymphohistiocytosis: diagnosis, pathophysiology, treatment and future perspectives. Annals of Medicine 2006; 38:20-31. http://dx.doi.org/10.1080/078538905004651 89

PMid: 1644898 